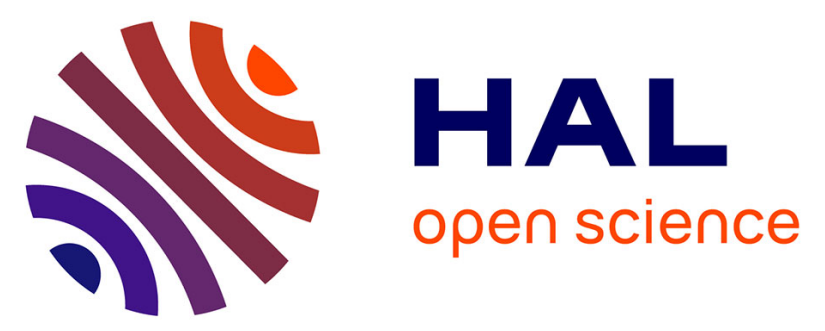

\title{
Macropharyngodon pakoko, a new species of wrasse (Teleostei: Labridae) endemic to the Marquesas Islands, French Polynesia
}

Erwan Delrieu-Trottin, Jeffrey T Williams, Serge Planes

\section{- To cite this version:}

Erwan Delrieu-Trottin, Jeffrey T Williams, Serge Planes. Macropharyngodon pakoko, a new species of wrasse (Teleostei: Labridae) endemic to the Marquesas Islands, French Polynesia. Zootaxa, 2014, 3857 (3), pp.433-443. 10.11646/zootaxa.3857.3.6 . hal-01333340

\section{HAL Id: hal-01333340 \\ https://hal-univ-perp.archives-ouvertes.fr/hal-01333340}

Submitted on 17 Jun 2016

HAL is a multi-disciplinary open access archive for the deposit and dissemination of scientific research documents, whether they are published or not. The documents may come from teaching and research institutions in France or abroad, or from public or private research centers.
L'archive ouverte pluridisciplinaire HAL, est destinée au dépôt et à la diffusion de documents scientifiques de niveau recherche, publiés ou non, émanant des établissements d'enseignement et de recherche français ou étrangers, des laboratoires publics ou privés.

\section{(c)(1)}

Distributed under a Creative Commons Attribution| 4.0 International License 
http://dx.doi.org/10.11646/zootaxa.3857.3.6

http://zoobank.org/urn:Isid:zoobank.org:pub:00F2C179-C509-483B-825F-C7EF4118B591

\title{
Macropharyngodon pakoko, a new species of wrasse (Teleostei: Labridae) endemic to the Marquesas Islands, French Polynesia
}

\author{
ERWAN DELRIEU-TROTTIN ${ }^{1}$, JEFFREY T. WILLIAMS ${ }^{2} \&$ SERGE PLANES ${ }^{1}$ \\ ${ }^{\prime}$ Laboratoire d'Excellence "CORAIL», USR 3278 CNRS - EPHE - UPVD, Centre de RechercheInsulaire et Observatoire de l'Envi- \\ ronnement(CRIOBE), Université de Perpignan, 58 Av. Paul Alduy - 66860 Perpignan cedex, France. \\ E-mail:erwan.delrieu.trottin@gmail.com \\ ${ }^{2}$ Division of Fishes, Department of Vertebrate Zoology, National Museum of Natural History, 4210 Silver Hill Road, Suitland, MD \\ 20746, USA
}

\begin{abstract}
A new species of wrasse, Macropharyngodon pakoko, is described from the Marquesas Islands, bringing the total number of species of the genus Macropharyngodon to 12. Macropharyngodon pakoko was found at depths from 0-42 $\mathrm{m}$ and is endemic to the Marquesas Islands. Macropharyngodon pakoko is similar to M. meleagris, which is widely distributed from the central and western Pacific to Cocos-Keeling in the Indian Ocean, but differs genetically and in several coloration characters: males with irregularly curved black humeral blotch with incomplete iridescent blue border; inverted irregular "U"shaped band on the cheek; a small black spot at the upper base of the pectoral fin; and background color of the body greenish with faint bluish black spots on each scale. Females lack black pigment on the chest posterior to the ventral attachment of the gill membranes; reddish black blotches on the body are widely spaced, particularly on the head where they are more reddish and half the size of those on body; caudal fin with small, bright yellow spots arranged in narrow vertical bands with pale interspaces; pelvic fins pale with three reddish yellow cross-bands; a small black spot at the upper base of the pectoral fin; and small reddish spots along the base of the anal fin. Juveniles have irregular black blotches on the body, a small black spot instead of an ocellus posteriorly on the dorsal fin and lack large black spots and ocellus on the anal fin.
\end{abstract}

Key words: wrasse, Macropharyngodon pakoko, French Polynesia, Marquesas Islands, endemic

\section{Introduction}

The Marquesas Islands, located in the South Pacific ( $\left.7^{\circ} 50^{\prime} \mathrm{S}-10^{\circ} 35^{\prime} \mathrm{S} ; 138^{\circ} 25^{\prime} \mathrm{W}-140^{\circ} 50^{\prime} \mathrm{W}\right)$, are composed primarily of high volcanic islands with almost no barrier reef, very little coral reef cover, plankton enriched waters as a result of the presence of upwelling zones, and highly variable sea temperatures - a combination of factors that are unique for an equatorial archipelago (Gaither et al. 2010, Randall 2001a, 2001b). These unusual environmental conditions may contribute to biogeographic isolation of the Marquesan fish fauna, as revealed by a strong genetic break found at the Marquesas for some widespread species (Planes \& Fauvelot 2002, Gaither et al. 2010) and the high rate of endemism at these islands, $11.6 \%$ (Randall \& Earle 2000), that could reach up to $12.9 \%$ according to Williams et al. (2013) as many species collected there remain undescribed.

We collected fish specimens in 2011 during an expedition to the Marquesas Islands, French Polynesia, in which every island in the group was visited and sampled using a variety of collecting techniques. Operating from the M.V. Braveheart, a diversity of habitats was explored through shallow and deep air dives (down to 50-55 m). Macropharyngodon meleagris was previously the only species of this genus reported from Marquesan waters (Randall 1978, Randall \& Earle, 2000; Randall 2005). However, Randall and Earle (2000) mentioned that the coloration of the male form of the Marquesan M. meleagris population differed from the pattern exhibited by males at other localities throughout its range and that further taxonomic investigation was needed. We collected 11 specimens (4 males, 4 females and 3 juveniles) of this new species during our survey and conducted an integrative taxonomic analysis. Morphological and molecular data are used in combination to reveal the existence of the new species described herein. 
Randall (1978) revised the Indo-Pacific labrid fish genus Macropharyngodon and described five new species for a total of nine recognized species. Shepard \& Meyer (1978) and Randall (2013) described two additional new species belonging to this genus. The new species of Macropharyngodon described herein brings the total number of recognized species of this genus to 12 .

\section{Material and methods}

Methods of counting and measuring specimens follow Randall (1972). Values for the holotype are presented first, with values for paratypes following in parentheses when different. The holotype and paratypes of the new species are deposited in the National Museum of Natural History, Smithsonian Institution, Washington, DC (USNM) and Muséum national d'Histoirenaturelle, Paris, France (MNHN). Abbreviations used: standard length (SL), head length (HL), and lateral line (LL). Morphometric data for the new species are presented in the description as proportional measurements of SL or HL, rounded to the nearest 0.1 .

To conduct our genetic analysis, whole genomic DNA was extracted from fin clips preserved in $96 \% \mathrm{EtOH}$. DNA extraction was performed using QIAxtractor (QIAGEN, Crawley) according to manufacturer's protocols. A fragment of the mitochondrial gene coding for cytochrome $\mathrm{C}$ oxidase subunit I (COI) was amplified with the primers designed by Ward et al. (2005). PCR amplifications and sequencing were performed following Williams et al. (2012) protocol. A 650 base-pair fragment from the new species of Macropharyngodon was sequenced and compared with COI sequences of congeners obtained from Genbank with a representative of the Labridae used as the outgroup (Table 1). All sequences are deposited in GenBank (Genbank Accession numbers KM217160 KM217166).

TABLE 1. Specimens included in the molecular analysis for this study.

\begin{tabular}{|c|c|c|}
\hline Species & Geographic locality & GenBank Accession number \\
\hline Bodianus perditio & New Caledonia & KC684995 \\
\hline Macropharyngodon bipartitus & Mozambique & JF493851 \\
\hline Macropharyngodon bipartitus & Madagascar & JF435046 - JF435049 \\
\hline Macropharyngodon bipartitus & Maldives & DQ164148 \\
\hline Macropharyngodon choati & Lizard Is., GBR & AY850774 \\
\hline Macropharyngodon choati & Bramble Reef, GBR & DQ164149 \\
\hline Macropharyngodon cyanoguttatus & Mauritius & DQ164150 \\
\hline Macropharyngodon geoffroy & Hawaii & JQ839547, DQ164151 \\
\hline Macropharyngodon kuiteri & Southern GBR & DQ164152 \\
\hline Macropharyngodon meleagris & Vietnam & FJ583630, FJ583631 \\
\hline Macropharyngodon meleagris & Tonga & FJ583632 - FJ583636 \\
\hline Macropharyngodon meleagris & Philippines & FJ583637, FJ583638 \\
\hline Macropharyngodon meleagris & Sri Lanka & FJ583639, FJ583644, FJ583645 \\
\hline Macropharyngodon meleagris & Philippines & FJ583640 - FJ583643 \\
\hline Macropharyngodon negrosensis & North Reef, GBR & DQ164154 \\
\hline Macropharyngodon negrosensis & Indonesia & JQ839549 \\
\hline Macropharyngodon negrosensis & Lizard Is., GBR & AY850773 \\
\hline Macropharyngodon pakoko & Marquesas & KM217160 - KM217166 \\
\hline Macropharyngodon ornatus & Sri Lanka & FJ583646, DQ164155 \\
\hline Macropharyngodon ornatus & Indonesia & JQ839550 \\
\hline
\end{tabular}


Two different tree-building methods were used to construct branching diagrams. Neighbor-joining (NJ) analysis based on the K2P model of sequence evolution was conducted using the software package MEGA 5 (Tamura et al. 2011). The ML analysis was run using the Geneious implementation of PHYML (Drummond et al. 2010, Guindon \& Gascuel 2003). The appropriate model of nucleotide substitution was determined using jModeltest version 3.07 (Posada 2008). Confidence in topologies was evaluated by a bootstrap analysis with 1000 replicates (Felsenstein 1985).

\section{Macropharyngodon pakoko new species}

Common Name: Pakoko Wrasse

Figure 1

Macropharyngodon meleagris (in part): Randall (1978); Randall et al. (2005: 424), Marquesas.

Holotype. USNM 409153; $72 \mathrm{~mm}$ SL when fresh (66.4 mm SL after preservation); terminal-phase male; French Polynesia, Marquesas Islands, Clark Banc, reef flat with detritic sand and slope; 08 $05^{\prime} 357^{\prime \prime} \mathrm{S}, 139^{\circ} 38^{\prime} 110^{\prime \prime} \mathrm{W}$; depth 15-35m; field number MARQ-2011-08; tissue voucher number MARQ-153; collected with rotenone and hand nets, collectors J.T. Williams, S. Planes, E. Delrieu-Trottin, P. Sasal \& J. Mourier, 28 Oct. 2011; vessel "Braveheart."

Paratypes. USNM 409154; $60 \mathrm{~mm}$ SL when fresh (55.9 mm SL after preservation); female form; tissue voucher number MARQ-154 and USNM 409155; $60 \mathrm{~mm}$ SL when fresh (50.1 mm SL after preservation); female form; tissue voucher number MARQ-155; collected with holotype. USNM 409259; $70 \mathrm{~mm}$ SL when fresh (67 mm SL after preservation); male form; French Polynesia, Marquesas Islands, west side of Motu One, sand, patch reef of Halimeda sp. on coral rock, and rubble on plateau at about $10 \mathrm{~m}$ depth; 07 $51^{\prime} 426^{\prime \prime} \mathrm{S}, 140^{\circ} 22^{\prime} 376^{\prime \prime} \mathrm{W}$; depth 8-42 m; field number MARQ-2011-16; tissue voucher number MARQ-259; collected with rotenone and hand nets, collectors J.T. Williams, S. Planes, E. Delrieu-Trottin, P. Sasal \& J. Mourier, 1 Nov. 2011; vessel "Braveheart". Collected with USNM 409259: USNM 409260; $67 \mathrm{~mm}$ SL when fresh (66.2 mm SL after preservation); male form; tissue voucher number MARQ-260; USNM 409261; $56 \mathrm{~mm} \mathrm{SL}$ when fresh (52 $\mathrm{mm}$ SL after preservation); tissue voucher number MARQ-261; and MNHN IC-2014-0150; $57 \mathrm{~mm}$ SL when fresh (56.6 mm SL after preservation); female form. USNM 409396; $35 \mathrm{~mm}$ SL when fresh (32.3 $\mathrm{mm}$ SL after preservation); French Polynesia, Marquesas Islands, Tahuata Island, on north end of island in small bay on a dead coral fringing reef with Halimeda sp. algae and sand; 09 $53^{\prime} 612^{\prime \prime S}, 139^{\circ} 05^{\prime} 039^{\prime \prime} \mathrm{W}$; 0-4 m depth; field number MARQ-2011-26; tissue voucher number MARQ-396; collected with rotenone and hand nets, collectors J.T Williams, S. Planes, E. DelrieuTrottin, P. Sasal, J. Mourier, 7 Nov. 2011; vessel "Braveheart". MNHN IC-2014-0151; 2 specimens, 69.3 mm SL and $31.0 \mathrm{~mm}$ SL after preservation; male and juvenile form, collected with USNM 409396. USNM 411453; 13.0 mm SL after preservation; juvenile form, French Polynesia, Marquesas Islands, Fatu Hiva Island, northwest end of island, small bay on north side of Pointe Teohootefau on rock, boulder and fine brown sand beach; $10^{\circ} 26^{\prime} \mathrm{S}$, $138^{\circ} 41^{\prime} \mathrm{W}$; 0-4 m depth; field number MARQ-2011-35; collected with rotenone and hand nets; collectors J.T Williams, S. Planes, E. Delrieu-Trottin, P. Sasal, J. Mourier; 11 Nov. 2011; vessel "Braveheart".

Diagnosis. Macropharyngodon pakoko can be distinguished from congeners by the following combination of characters: dorsal rays IX, 11; anal rays III, 11; pectoral rays 12 (including upper rudimentary ray); anterior lateralline scales with 2 or 3 pores, gill rakers 17 (15-17). Color pattern of females: no black spot on chest at base of gill openings; spots on body widely spaced, particularly on head; caudal fin with small bright yellow spots in vertical rows; pelvic fins pale with three cross-bands of reddish orange to yellow; small reddish spots along the base of anal fin. Male body green, the scales with a dark purplish brown bar, those laterally and ventrally on body with bar preceded by a blue line; curved black humeral blotch, outlined with iridescent blue followed by a broad, irregular longitudinal band of a dark yellow-orange network superimposed over and adjacent to the bar pattern on the scales; head green with an anastomosing pattern of red bands edged with dark purple and iridescent blue; inverted irregular "U"- shaped band on cheek; small black spot at upper base of pectoral fin; dorsal and anal fins reddish with blue-ringed green spots with black border, some spots merging and forming vertical reticulations; caudal fin with reddish reticulations around greenish yellow spots with black borders, distal margin with broad red band followed by black outline then whitish tips on rays ; pelvic fin translucent or colors, outermost rays faintly reddish yellow, innermost rays translucent. Juveniles: few irregular black blotches on body with irregular red bars on anal 
fin broadly joined distally with yellow. A small black spot instead of an ocellus posteriorly on the dorsal fin and lack of a large black spots and ocellus on the anal fin.
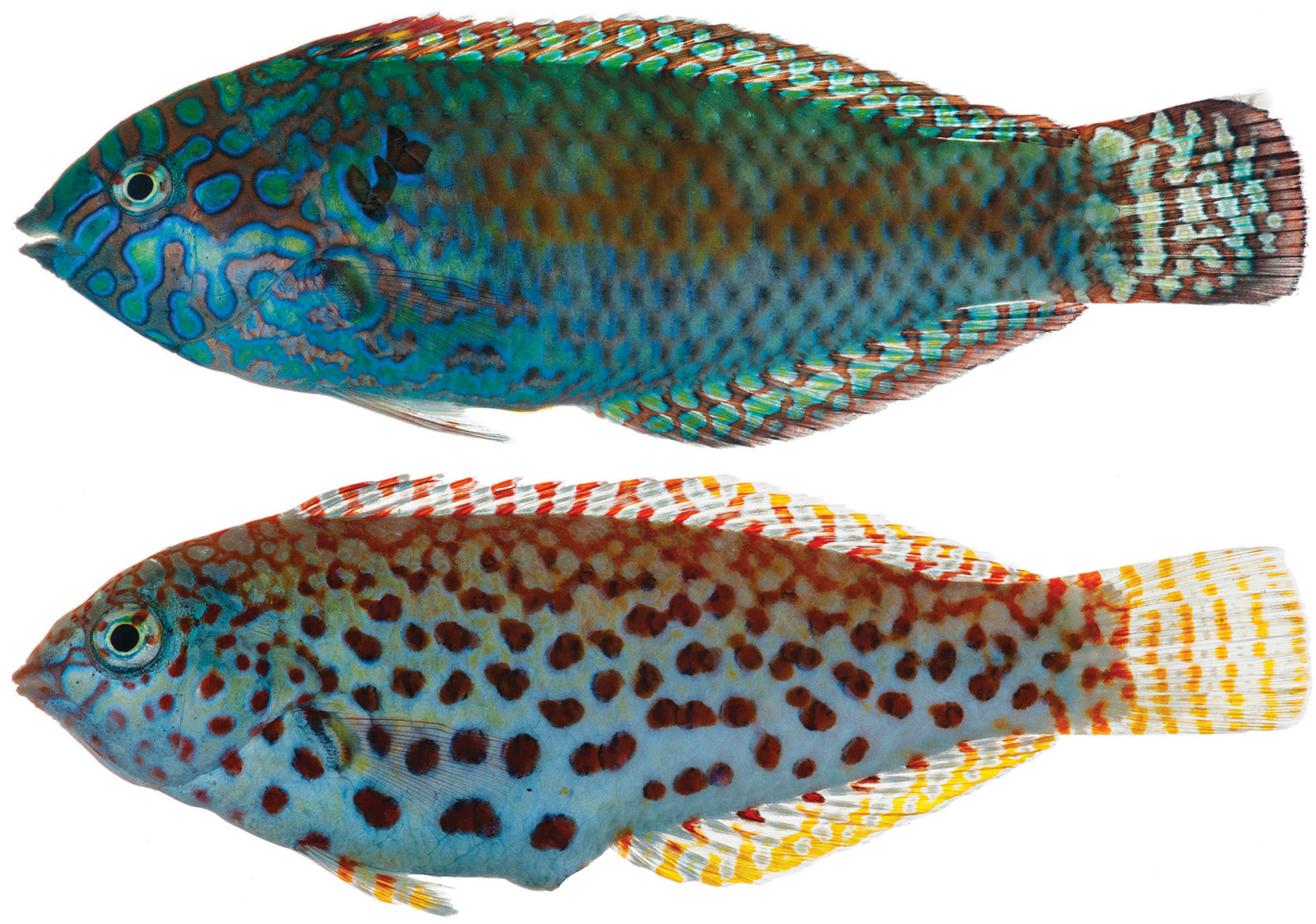

FIGURE 1. Male (top) and female (bottom) color patterns of Macropharyngodon pakoko: top USNM 409153, $72 \mathrm{~mm}$ SL, male, holotype; bottom USNM 409154, $60.0 \mathrm{~mm}$ SL, female, paratype. Photographs by Jeffrey T. Williams.

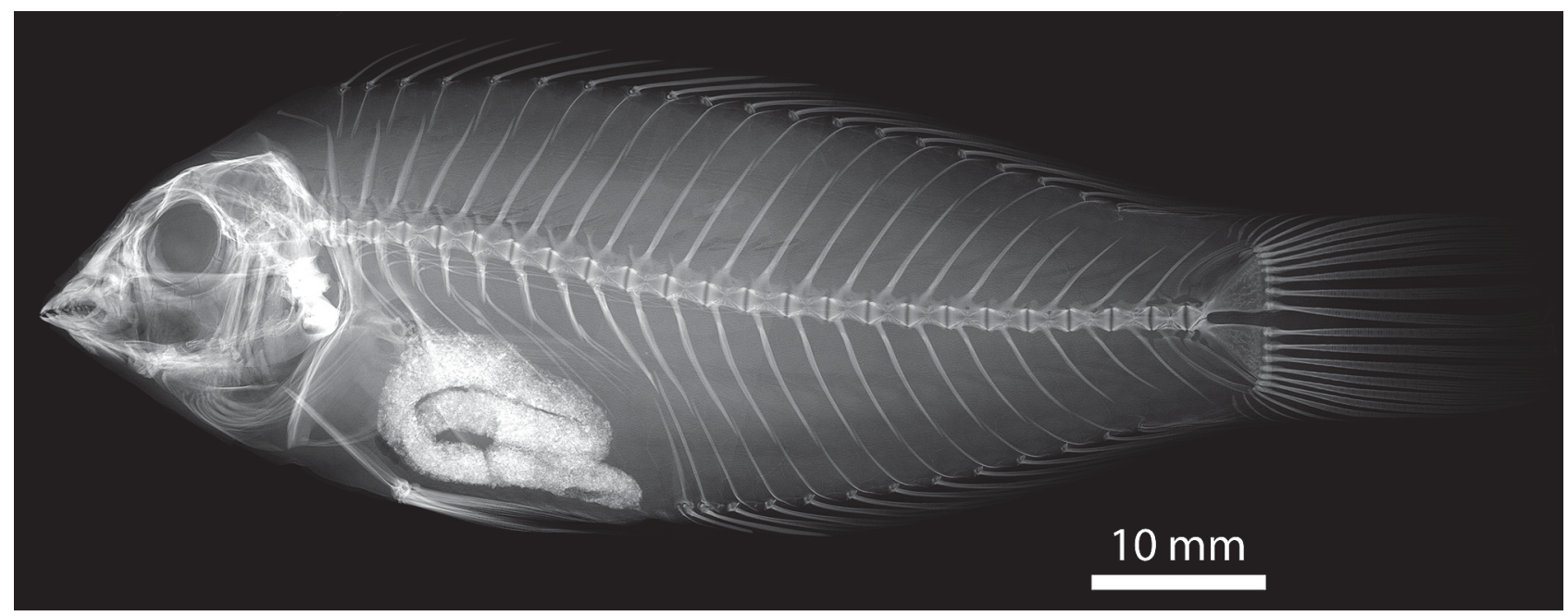

FIGURE 2. Radiograph of holotype of Macropharyngodon pakoko, USNM 409153, 72 mm SL, Marquesas Islands. 
Description. Dorsal rays IX, 11; anal rays III, 11; pectoral rays 12 (including upper rudimentary ray); 14 principal caudal rays; pelvic-fin rays I, 5; lateral line continuous, arched over pectoral fin, angling downward below posterior three or four dorsal rays, then becoming straight along midbody for peduncular portion, 27 pored scales (plus one on base of caudal fin); anterior lateral-line scales with 2 or 3 pores, gill rakers 17 (15-17); 25 vertebrae, last rib on vertebral centrum 9, last epineural on vertebral centrum 14 (Fig. 2); body depth 2.7 in SL (2.7-3.0); body width 7.4 in SL (7.0-8.5); head length 3.2 (2.9-3.2) in SL; snout 3.2 (3.2-4.0) in HL; orbit diameter 4.6 (4.4-5.1) in HL; interorbital width 3.7 (3.5-4.3) in HL; suborbital depth 0.2 (0.1-0.2) in HL; upperjaw length 5.0 (4.5-5.9) in HL; least depth of caudal peduncle 1.9 (1.9-2.2) in HL; caudal-peduncle length 3.0 (2.3-3.8) in HL; caudal fin slightly rounded, $0.8(0.7-0.8)$ in HL; pectoral fin 1.4 (1.5-1.6) in HL; pelvic fins not reaching the anus, 1.7 (1.7-1.9) in HL; first dorsal spine 3.3 (3.3-4.2) in HL; remaining dorsal spines progressively longer; longest (usually fifth or sixth) 2.3 (2.6-3.4) in HL; first anal spine 6.3 (3.5-6.5) in HL, third anal spine 1.9 (2.1-2.7) in HL.

Upper jaw with two pairs of large canines, the first pair straight and strongly projecting forward, the second pair smaller and recurved, 5-7 progressively smaller pointed teeth along side of jaw, except for pair of large canines at corner of mouth (nearly as large as anterior pair of canines); lower jaw with two pairs of enlarged canine teeth anteriorly, straight to slightly curved, second pair shorter; 6-7 progressively smaller teeth on side of jaw, large molariform teeth on lower pharyngeal plate are characteristic of the genus.

Color of females when fresh (Fig. 1). Body whitish to pale yellowish green dorsally becoming bluish-white ventrally with irregular widely separated reddish to reddish brown pupil-sized spots, some joined; nape with reticulated pattern of reddish orange lines, sometimes continuing along top of body to caudal peduncle; dark reddish bands cross inter-orbital space; small reddish spots on cheek and onto opercle; pectoral fins pale with faint dark bar at base and small black spot at upper base of pectoral fin; yellowish-olive bar along pectoral axil; pelvic fins whitish with about three red and yellow bars; dorsal fin pale with reddish and reddish-yellowish diagonal bars; anal fin pale with seven to nine small red spots basally, with yellow streak radiating anteroventrally from each red spot, the yellow streaks fuse distally forming yellow margin along anal fin, yellow streaks alternating with dusky centered pale interspaces through middle portion of fin; caudal fin pale with five to six columns of yellow spots giving appearance of narrow bars alternating with dusky centered pale interspaces.

Color of females in alcohol. Body pale with irregularly spaced black spots, some joined; no spots along dorsum from snout to caudal peduncle; cheeks with faint remnants of red spots seen in fresh specimens; distal margin of dorsal and anal fins dusky; caudal fin and paired fins pale; dorsal fin pale with or without row of dark spots at base; anal fin with row of five to seven dark spots basally.
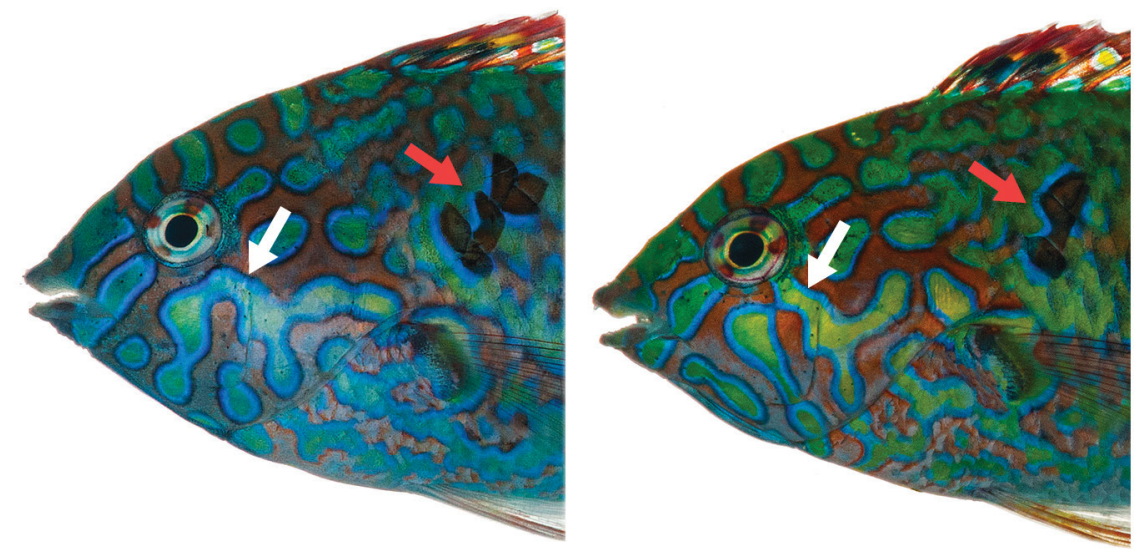

FIGURE 3. Cropped heads of Macrpharyngodon pakoko holotype (USMN 409153, $72 \mathrm{~mm}$ ) and paratype (USMN 409260, 67 $\mathrm{mm}$ ). Note the variations in (i) the greenish irregular inverted "U"-shaped band under the cheek (white arrow) and (ii) the irregularly shaped black humeral blotch on shoulder incompletely outlined with iridescent blue (red arrow). Photographs by Jeffrey T. Williams.

Color of males when fresh (Fig. 1). Ground color of males body yellowish green to bluish green with increasing size, with three to four irregular faint orange to orangish brown blotch-like bars midlaterally along body, 
each scale with narrow iridescent blue bar followed posteriorly by dusky blotch at center; head with reticulating reddish and green areas with each green area outlined with iridescent blue then narrow black margin, reddish bars radiate from eye, dark reddish bands cross the green inter-orbital space, cheek with greenish irregular inverted "U" - shaped band (Fig. 3); irregularly shaped black humeral blotch on shoulder incompletely outlined with iridescent blue (Fig. 3); reticulating network of reddish bands on head and extending posteriorly to about level of tip of pectoral fin; black stripe along ventral midline from chin to gill opening where it terminates in black spot on breast; ground color of dorsal and anal fins reddish with whitish - bluish-ringed green spots with black border, forming 3 rows, some spots merging, two black spots with first yellow then dark red dorsal margins positioned over middle of anterior dorsal-fin spines; narrow dusky white margin on dorsal and anal fins; pectoral fins translucent with faint dark bar at base and a small black spot at upper base of pectoral fin, half circled with bluish-ringed olive-greenish spot with black border; caudal fin with reddish reticulations around greenish yellow spots with black borders, some of which merge to form vertical bands, distal margin with broad red band followed by black posterior margin then whitish tips on rays forming a narrow dusky white margin; pelvic fin with outermost rays reddish yellow, innermost rays translucent.
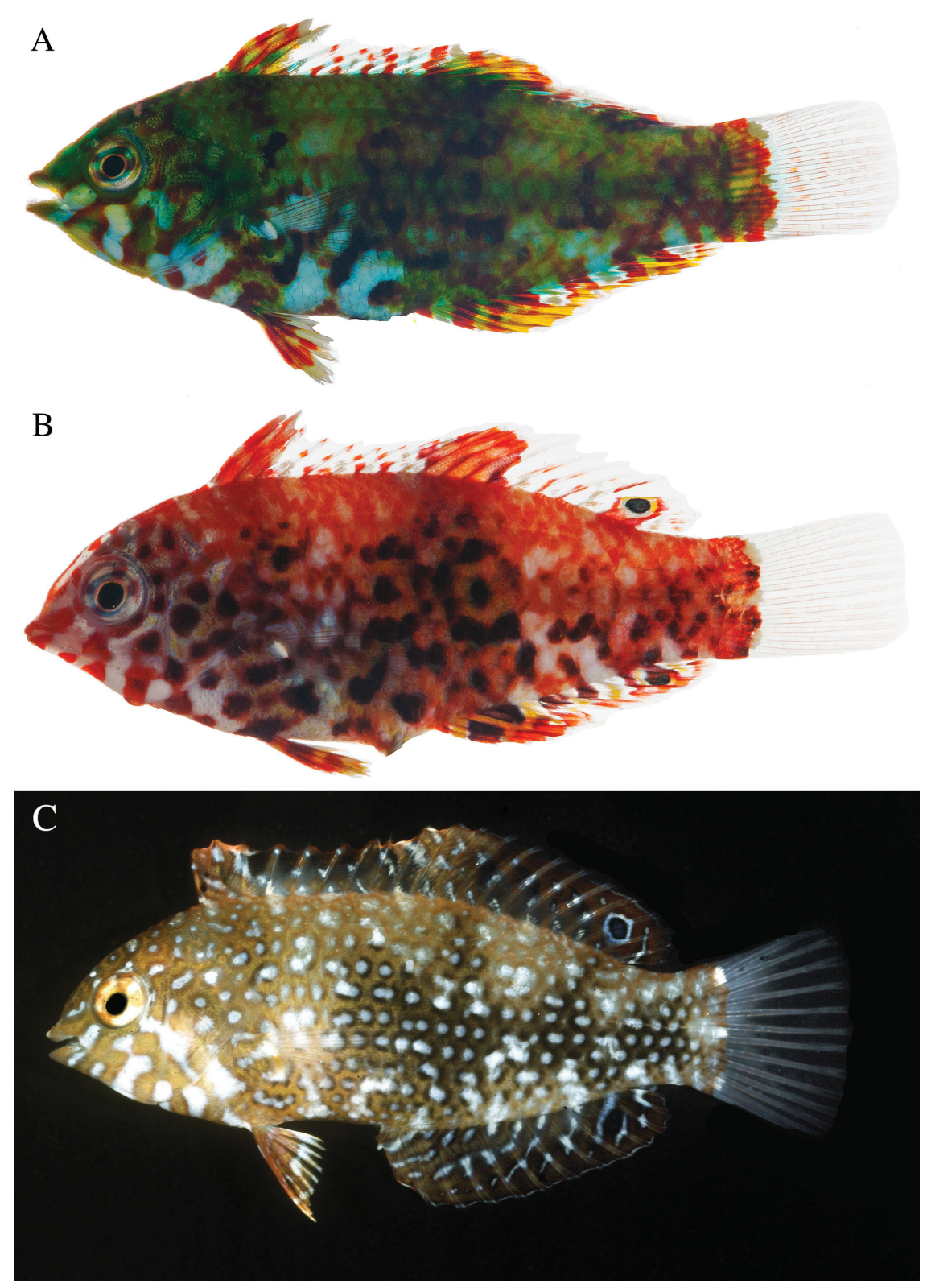

FIGURE 4. Juvenile color patterns of: A Macropharyngodon pakoko, USNM 409396, $35 \mathrm{~mm}$ SL, from Marquesas Islands, French Polynesia, B Macropharyngodon melagris USNM 423323, $32.5 \mathrm{~mm}$ SL, from Australs Islands, C Macropharyngodon geoffroy BPBM 13355, 39 mm SL, from Hawai'i Islands. A, B: Photographs by Jeffrey T. Williams, C: Photograph by John E. Randall. 


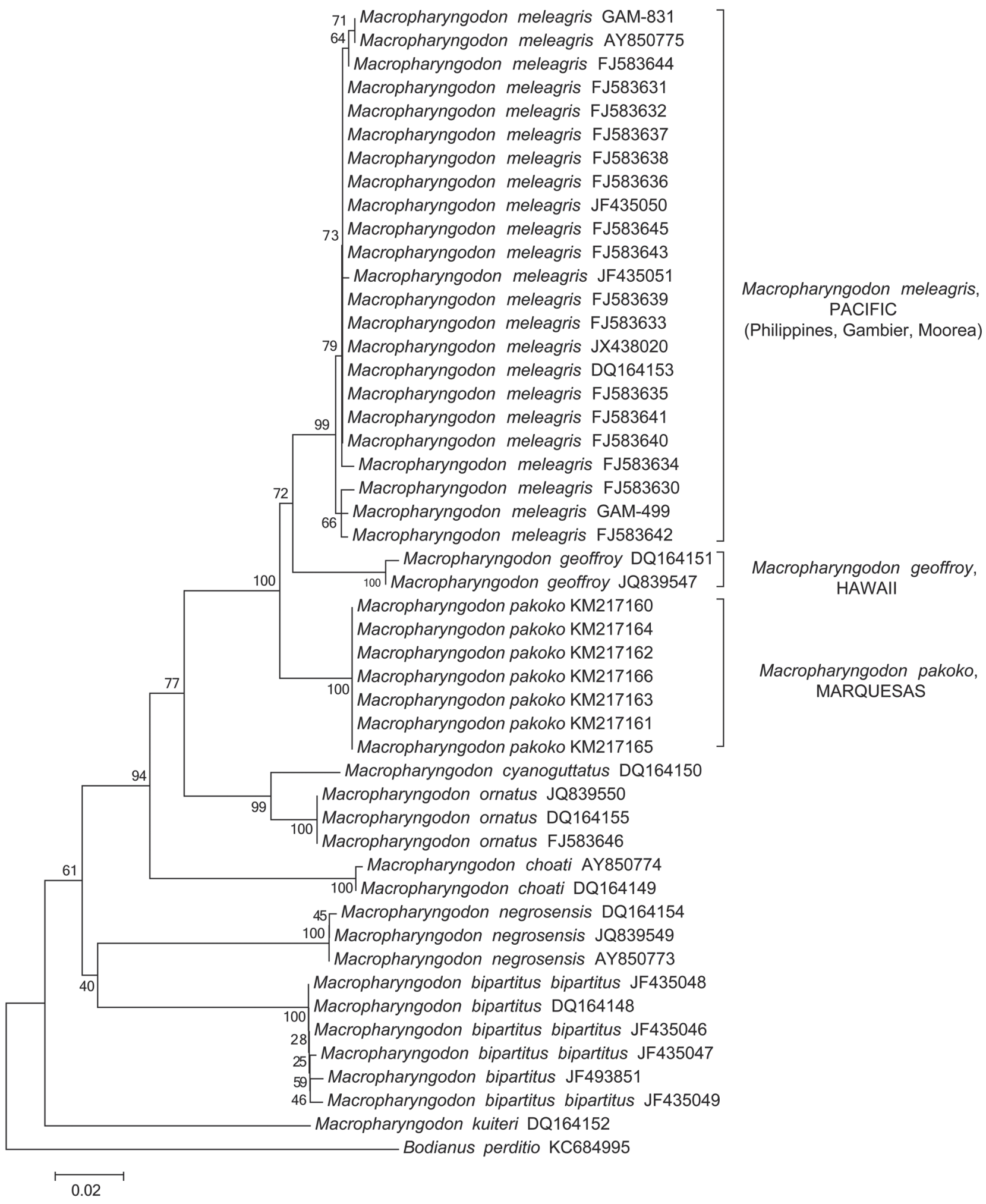

FIGURE 5. Neighbor-Joining tree based on K2P model of sequence evolution (with 1,000 bootstrap replicates) for available members of the genus Macropharyngodon. The scale bar at left represents a 2\% sequence difference. Alpha-numberic codes following each species name are the GenBank accession numbers. See Table 1 for locality data for each sample.

Color of male in alcohol is similar except green, blue and yellow markings pale and reddish markings on head and fins blackish.

Juvenile color when fresh greenish brown with brownish black blotches on body (Fig. 4). Elongate first three spines of dorsal fin mottled with red, green and yellow with distal tips whitish, central spines translucent with small 
red and blue spots, first four to five and posteriormost soft rays mottled with green, red and yellow, middle rays of soft dorsal translucent with small red and blue spots, a small black spot (not ocellated) posteriorly on the dorsal fin. Anal fin with irregular green, red and yellow bars with yellow bars merging distally to form yellow margin. Caudal fin pale with faint reddish bars, basally mottled with red, yellow and green. Faint red spots present on caudal fin resembling basal spots of initial phase females. Belly and breast white with black blotches on belly, red blotches on breast. Cheek with three reddish bordered white bars radiating from ventral portion of eye. Narrow white bars cross interorbital space.

Color of juvenile in alcohol is similar except green, yellow and red areas are pale.

Molecular analysis. Molecular data were examined for 9 of the 12 species of the genus (Table 1) and includes the hypothesized (based on color and morphological characters) closest relatives of M. pakoko. Two analyses (NJ and ML) resulted in identical tree topologies (Fig. 5). The topology of our trees (Fig. 5) is similar to that of Read et al. (2006) based on COI but also 12S and 16S rRNA mitochondrial sequences. Our mtDNA analysis reveals a wellsupported genetic divergence between M. pakoko and its congeners (Fig. 5).

Etymology. The specific epithet pakoko refers to the famous Marquesan warrior Pakoko, the last chieftain who led the Marquesan resistance to the French during his time (died in 1984). He is still celebrated in the Marquesas and an important figure in the community. The common name Pakoko Wrasse derives from the species epithet. The name is treated as a noun in apposition.
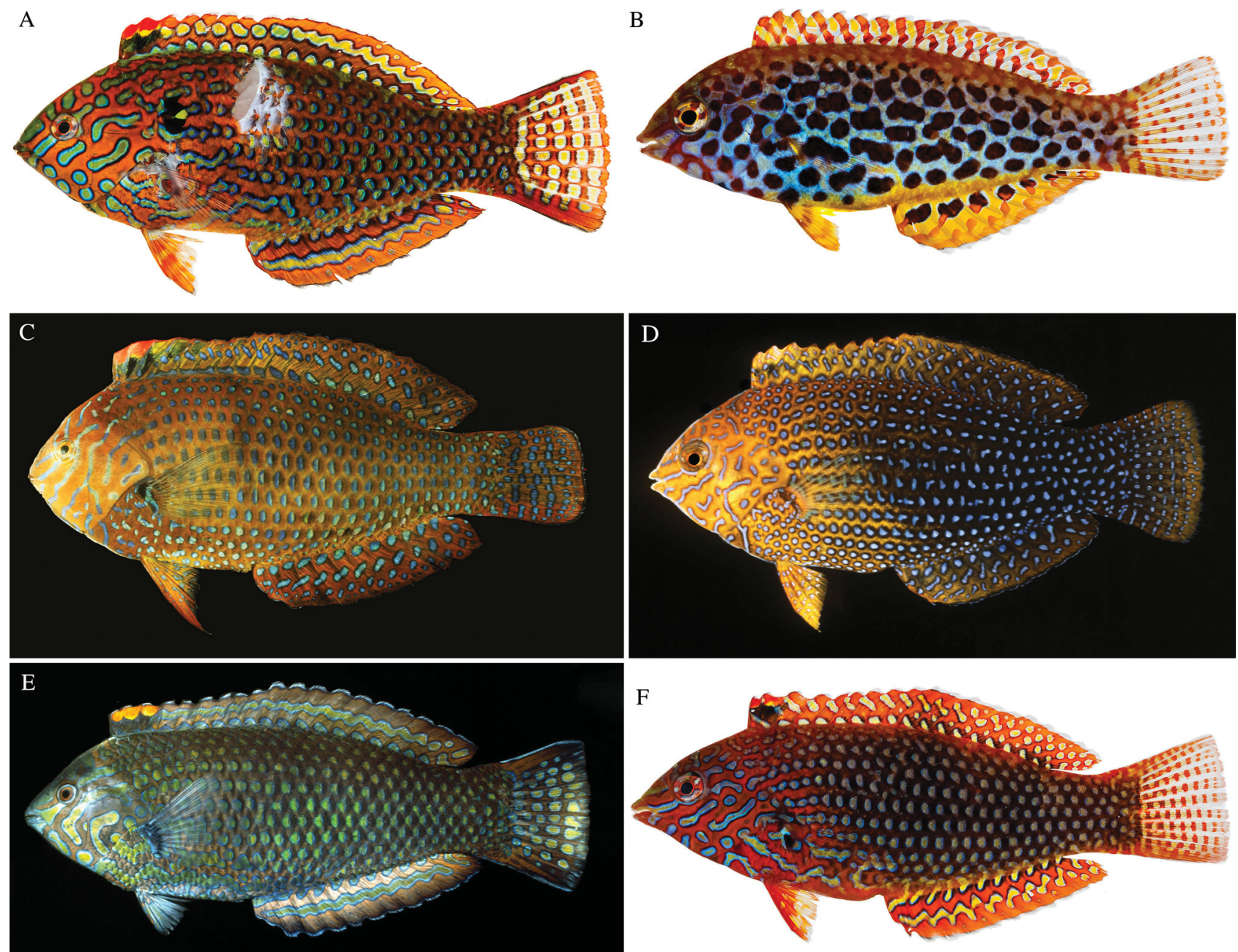

FIGURE 6. Male and female color patterns of Macropharyngodon meleagris (A-B), Macropharyngodon geoffroy (C-D) and Macropharyngodon ornatus (E-F): AUSNM 392209, 79.7 mm SL, male, from Moorea, French Polynesia (damaged body from a spear used to collect the specimen). B USNM 424887, $51.4 \mathrm{~mm} \mathrm{SL}$, female, from Palau..C BPBM 8493, $110 \mathrm{~mm} \mathrm{SL}$, male, from Oahu, Hawaii, D BPBM 29621, 69 mm SL, female, from Johnston Island, E BPBM 18546, 116 mm SL, male, from Ambon, Indonesia,F USNM 424486, 84.5 mm SL, female, from Palau. A, B, F: Photographs by Jeffrey T. Williams; C, D, E Photographs by John E. Randall. 


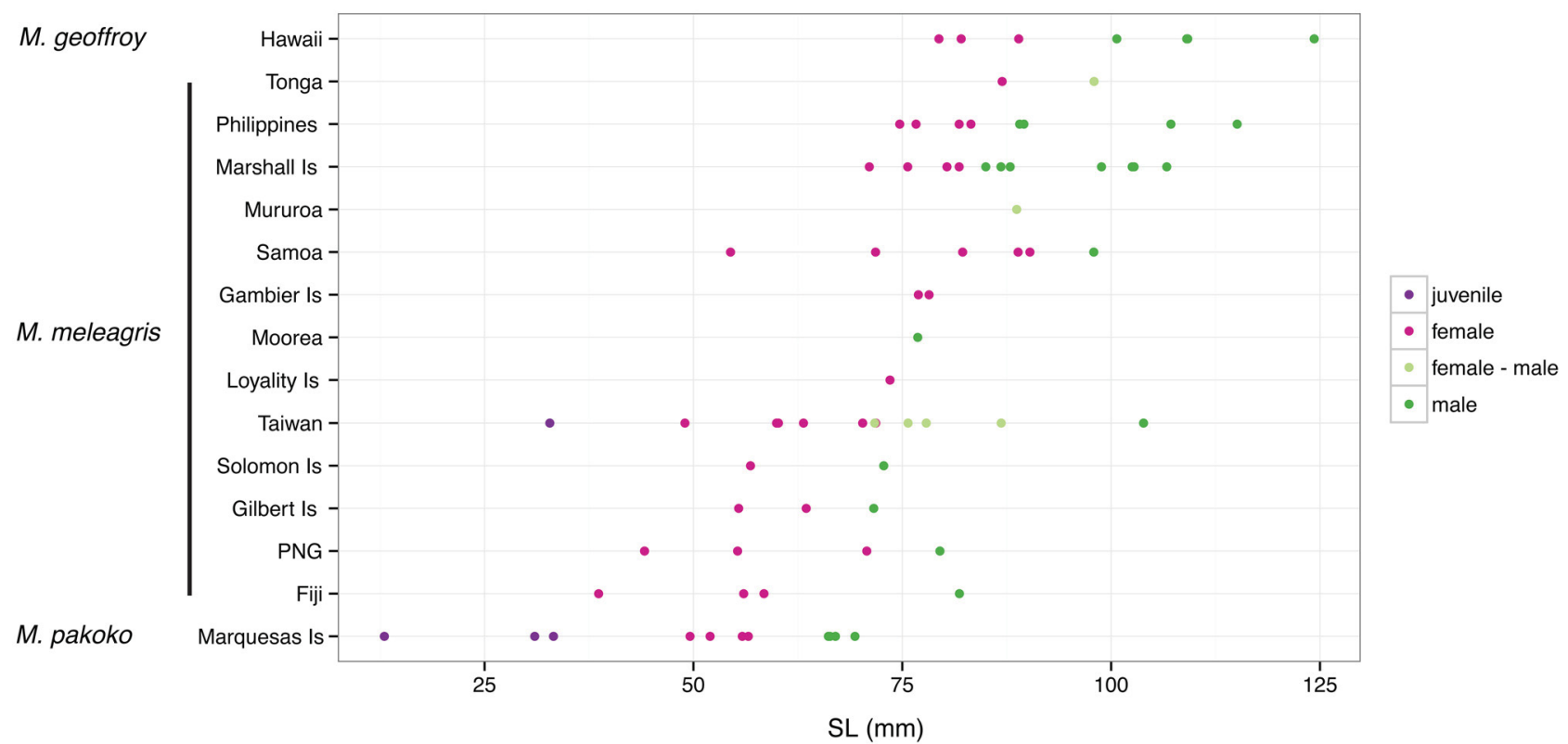

FIGURE 7. Standard length, sex and locality for Macropharyngodon geoffroy, M. pakoko and M. meleagris. Material used: M. geoffroy: Hawai'i: USNM 368249 (2 specimens), USNM 368252 (1 specimen), USNM 160625 (1 specimen), USNM 368251 (1 specimen), USNM 51142 (1 specimen), USNM 368250 (1 specimen); M. meleagris: Fiji: USNM 244021 (2 specimens), USNM 287794 (2 specimens); Gambier Islands: USNM 404734 (2 specimens); Gilbert Islands: USNM 167366 (2 specimens), USNM 167367 (1 specimen); Loyalty Island: USNM 323928 (1 specimen), Marshall Islands: USNM 113346 (4 specimens), USNM 113339 (3 specimens), USNM 113333 (4 specimens), Moorea: USNM 392209 (1 specimen), Mururoa: USNM 409704 (1 specimen), Philippines: USNM 392106 (2 specimens), USNM 152986 (1 specimen), USNM 153245 (1 specimen), USNM 378674 (1 specimen), USNM 153243 (1 specimen), USNM 259300 (1 specimen), USNM 295574 (1 specimen), Papua New Guinea (PNG): USNM 368254 (1 specimen), USNM 368256 (1 specimen), USNM 232089 (1 specimen), USNM 368258 (1 specimen), Solomon Islands: USNM 389506 (1 specimen), USNM 385722 (1 specimen), Samoa: USNM 52304 (1 specimen), USNM 115609 (2 specimens), USNM 052230 (3 specimens), Taiwan: USNM 277573 (1 specimen), USNM 277453 (1 specimen), USNM 368253 (1 specimen), USNM 277437 (5 specimen), USNM 277457 (4 specimens), Tonga: USNM 334627; M. pakoko: Marquesas Islands: USNM 409153 (1 specimen), USNM 409154 (1 specimen), USNM 409155 (1 specimen), USNM 409259 (1 specimen), USNM 409260 (1 specimen), USNM 409261 (1 specimen), MNHN IC-2014-0150 (1 specimen), USNM 409396 (1 specimen), MNHN IC-2014-0150 (2 specimens), USNM 411453 (1 specimen).

Remarks. Read et al. (2006) note that the species of Macropharyngodon are relatively uniform both ecologically and morphologically. In Randall's (1978) key to the then known taxa (10 taxa included in the key), morphological characters distinguished only three of the taxa with life color characters needed to differentiate the remaining seven taxa. Our analysis of available molecular data (nine species) show clear genetic differentiation of all nine lineages that support the color pattern characters differentiating these nine morphologically similar taxa. Macropharyngodon pakoko is most similar morphologically and in color pattern to the relatively widespread $M$. meleagris, which is known in the Pacific and the eastern Indian Ocean from Cocos (Keeling) Islands to Southern Japan and the Great Barrier Reef, Lord Howe Island, and New Caledonia, east to the Line Islands and French Polynesia, except Rapa and the Marquesas. Although these two species have broadly overlapping morphological characters, they are readily distinguished genetically and by their diagnostic colour patterns. These two species are in turn similar to $M$. geoffroy (endemic to Hawaii) and M. ornatus (found in the Indian and western Pacific Oceans), but again differ genetically and by their diagnostic colour patterns.

Initial phase females of Macropharyngodon pakoko lack the distinctive black spot on the chest at the base of the gill openings, which is present on M. meleagris females (Fig. 6); black spots on the body of M. pakoko are more widely spaced compared to those of M. meleagris, particularly on the head. In alcohol, the head of female $M$. pakoko lacks the distinct dark spots, which are present on female M. meleagris. The caudal fin of M. pakoko has brilliant yellow spots while the caudal fin of $M$. meleagris has orange to reddish spots; the pelvic fins are pale with three reddish to yellow cross-bands, versus the pelvic fins of $M$. meleagris being yellow with or without three cross-bands of dark red. M. pakoko has small reddish spots along the base of the anal fin, versus a row of distinctive, large dark spots along the basal third of the anal fin of M. meleagris. Female M. geoffroy and M. 
ornatus (Fig. 6) have no black spots on the body, but have small blue spots centered on the scales of the body and have an orange to orangish brown background color.

Terminal phase male Macropharyngodon pakoko have a humeral spot outlined with iridescent blue, whereas M. meleagris males (Fig. 6) have one to three smaller bright yellow spots bordering the humeral spot; M. pakoko has an inverted irregular "U"- shaped marking on the cheek, while the cheek markings on the head of M. meleagris are arranged as two broken diagonal green bars beneath eye and extending from above posterior end of upper jaw toward upper angle of gill opening; the background color of M. pakoko body is greenish to brownish green and lacks defined blue and green spots or stripes, while the background of M. meleagris male body is orangish brown with well-defined blue outlined green spots and broad stripes formed from fused spots. Male M. geoffroy and $M$. ornatus (Randall in FishBase) lack the black humeral spot of M. pakoko.

Juvenile color is similar to that of Macropharyngodon meleagris, but the latter has distinctive black spots on the anal fin like the initial phase females (no black spots on anal fin of M. pakoko at a similar size). M. geoffroy juveniles have small white or bluish white spots on the body that are absent on M. pakoko and M. meleagris juveniles.

We compared the size of the known specimens of M. pakoko to the size of 57 specimens of M. meleagris (1 juvenile, 32 initial phase females, 6 females transitioning into terminal phase males and 18 terminal phase males) from 14 locations across the Pacific and 7 specimens of $M$. geoffroy ( 3 females, 4 males) endemic to Hawai'i (Fig. 7). The largest females examined measure $56.5 \mathrm{~mm}, 82 \mathrm{~mm}, 89 \mathrm{~mm}$ while the smallest males measure $66 \mathrm{~mm}, 71.5$ $\mathrm{mm}$ and $100.5 \mathrm{~mm}$, respectively, for M. pakoko, M. meleagris and M. geoffroy. The transformation of initial phase females into terminal phase males for M. pakoko seems to occur at a smaller size for M. pakoko.

\section{Acknowledgments}

This study was part of the Pakaihi i te Moana expedition organized and funded by the Agence des Aires Marines Protégées in France. We thank the Centre Plongée Marquises (Xavier (Pipapo) and Marie Curvat), l'Agence des Aires Marines Marine Protégées, the Fondation TOTAL, the Ministère de l'Environnement de Polynésie, the Délégation à la Recherchede Polynésie, the Mairie of Nuku-Hiva, and the people of the Marquesas Islands for their kind and generous support of the project as we traveled throughout the islands. Particular thanks to the Captain and crew of the M/V "Braveheart" for their invaluable assistance during the Marquesas Expedition. We thank Jerry Finan, Diane Pitassy, Erika Wilbur, Shirleen Smith, Kris Murphy, David Smith and Sandra Raredon of the Division of Fishes (National Museum of Natural History) for assistance in preparations for the trip and processing specimens. Lee Weight, Amy Driskell and Jeff Hunt of the Laboratories of Analytical Biology (Smithsonian Institution) provided support for molecular analysis of samples. We are especially grateful to Tom Cribb, Rene Galzin, Pierre Sasal and Johann Mourier for their field assistance collecting fishes in the Marquesas. We thank the staff of the CRIOBE for logistical support, particularly Yannick Chancerelle for his assistance with arrangements for shipments into and out of French Polynesia. The first author's travel to Washington to examine fish collections and the second author's travel to Moorea to participate in the expedition were funded by grants from the Leonard P. Schultz Fund (Division of Fishes, National Museum of Natural History). Jack Randall generously provided the photographs of Macropharyngodon geoffroy and of the Macropharyngodon ornatus from Indonesia. We are grateful to Jack Randall, Loreen R. O'Hara and Arnold Y. Suzumoto who provided information regarding Bernice Pauahi Bishop Museum specimens. We thank Jack Randall and Mark Erdmann for providing constructive reviews of an earlier version of the manuscript.

\section{References}

Drummond, A., Ashton, B., Cheung, M., Cooper, A., Duran, C., Field, M., Heled, J., Kearse, M., Markowitz, S., Moir, R., Stones-Havas, S., Sturrock, S., Thierer, T. \& Wilson, A. (2009) Geneious v4.6. Available from: http://www.geneious.com/ (accessed 13 February 2014)

Felsenstein, J. (1985) Confidence limits on phylogenies: an approach using the bootstrap. Evolution, 39, $783-791$.

Gaither, M.R., Toonen, R.J., Robertson, D.R., Planes, S. \& Bowen, B.W. (2010) Genetic evaluation of marine biogeographical barriers: perspectives from two widespread Indo-Pacific snappers (Lutjanus kasmira and Lutjanus fulvus). Journal of Biogeography, 37, 133-147. 
http://dx.doi.org/10.1111/j.1365-2699.2009.02188.x

Guindon, S. \& Gascuel, O. (2003) A simple, fast, and accurate algorithm to estimate large phylogenies by maximum likelihood.Systematic Biology, 52, 696-704. http://dx.doi.org/10.1080/10635150390235520

Planes, S. \& Fauvelot, C. (2002) Isolation by distance and vicariance drive genetic structure of a coral reef fish in the Pacific Ocean. Evolution, 56, 378-399

Posada, D. (2008) jModelTest: Phylogenetic Model Averaging. Molecular Biology and Evolution, 25, 1253-1256. http://dx.doi.org/10.1093/molbev/msn083

Randall, J.E. \& Earle, J.L. (2000) Annotated checklist of the shore fishes of the Marquesas Islands. Bishop Museum Occasional Papers, 66, 1-9.

Randall, J.E. (1972) A revision of the labrid fish genus Anampses. Micronesica, 8, 151-195.

Randall, J.E. (1978) A revision of the Indo-Pacific labrid fish genus Macropharyngodon, with descriptions of five new species, Bulletin of Marine Science, 28, 742-770.

Randall, J.E. (2001a) Four New Cardinalfishes (Perciformes: Apogonidae) from the Marquesas Islands. Pacific Science, 55, 47-64.

Randall, J.E. (2001b) Four New Damselfishes (Perciformes: Pomacentridae) from the Marquesas Islands. Copeia, 92-107.

Randall, J.E. (2005) Reef and Shore Fishes of the South Pacific: New Caledonia to Tahiti and the Pitcairn Islands. University of Hawaii Press, Honolulu, 707 pp.

Randall, J.E. (2013) Seven new species of labrid fishes (Coris, Iniistius, Macropharyngodon, Novaculops, and Pteragogus) from the Western Indian Ocean. Journal of the Ocean Science Foundation, 7, 1-43.

Read, C.I., Bellwood, D.R. \& van Herwerden, L. (2006) Ancient origins of Indo-Pacific coral reef fish biodiversity: A case study of the leopard wrasses (Labridae: Macropharyngodon). Molecular Phylogenetics and Evolution, 38, 808-819. http://dx.doi.org/10.1016/j.ympev.2005.08.001

Shepard, J.W. \& Meyer, K.A. (1978) A new species of the labrid fish genus Macropharyngodon from southern Japan. Japanese Journal of Ichthyology, 25, 159-164.

Tamura, K., Peterson, D., Peterson, N., Stecher, G., Nei, M. \& Kumar, S. (2011) MEGA5: Molecular Evolutionary Genetics Analysis using Maximum Likelihood, Evolutionary Distance, and Maximum Parsimony Methods. Molecular Biology and Evolution, 28, 2731-2739. http://dx.doi.org/10.1093/molbev/msr121

Ward, R.D., Zemlak, T.S, Innes, B.H., Peter, R. Last, P.R. \& Hebert, P.D.N. (2005) DNA barcoding Australia's fish species. Philosophical transactions of the Royal Society B, 360, 1847-1857. http://dx.doi.org/10.1098/rstb.2005.1716

Williams, J.T., Delrieu-Trottin, E. \& Planes, S. (2012) A new species of Indo-Pacific fish,Canthigaster criobe, with comments on other Canthigaster (Tetraodontiformes: Tetraodontidae) at the Gambier Archipelago. Zootaxa, 352, 80-88.

Williams, J.T., Delrieu-Trottin, E. \& Planes, S. (2013) Two new fish species of the subfamily Anthiinae (Perciformes, Serranidae) from the Marquesas. Zootaxa, 3647 (1), 167-180.

http://dx.doi.org/10.11646/zootaxa.3647.1.8 